\title{
Effects of Support on the Performance of NiO-Based Oxygen Carriers
}

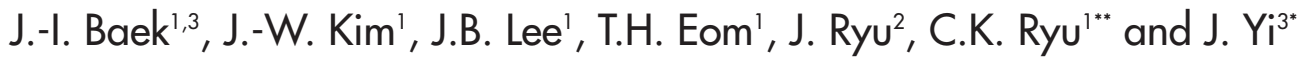 \\ 1 KEPCO Research Institute, Munji-ro 65, Yuseong-gu, Daejeon 305-380 - Republic of Korea \\ 2 Korea Institute of Geoscience and Mineral Resources, Gwahang-no 92, Yuseong-gu, Daejeon 305-350 - Republic of Korea \\ 3 School of Chemical and Biological Engineering, Institute of Chemical Process, Seoul National University, \\ San 56-1, Shillim, Kwanak, Seoul 151-742 - Republic of Korea \\ e-mail: perbaek@kepco.co.kr - landbear@daum.net - jblee7@kepri.re.kr - pantyeom@kepco.co.kr \\ iryu@kigam.re.kr - ckryu@kepri.re.kr - jyi@snu.ac.kr \\ * Corresponding author \\ ** Co-corresponding author
}

\begin{abstract}
Résumé - Effets du support sur les performances de matériaux transporteurs d'oxygène à base d'oxyde de nickel - Les performances des matériaux transporteurs d'oxygène varient en fonction du support utilisé dans le procédé de combustion en boucle chimique. Différents matériaux à base d'oxyde de Nickel ont été synthétisés avec des concentrations élevées en $\mathrm{NiO}$, comprises entre 60 et $70 \%$, sur différents supports $\left(\gamma-\mathrm{Al}_{2} \mathrm{O}_{3}\right.$, pseudobohémite, $\alpha-\mathrm{Al}_{2} \mathrm{O}_{3}, \gamma-\mathrm{Al}_{2} \mathrm{O}_{3}$ mélangée avec $\mathrm{MgO}$, hydrotalcite, $\mathrm{MgAl}_{2} \mathrm{O}_{4}$ et $\gamma-\mathrm{Al}_{2} \mathrm{O}_{3}$ additivées avec du graphite) par mélange mécanique. Des tests de réactivité ont été conduits dans une thermobalance (ATG) à $950^{\circ} \mathrm{C}$. Les matériaux supportés avec $\gamma-\mathrm{Al}_{2} \mathrm{O}_{3}, \gamma-\mathrm{Al}_{2} \mathrm{O}_{3}$ mélangée avec $\mathrm{MgO}$, l'hydrotalcite et $\mathrm{MgAl}_{2} \mathrm{O}_{4}$ ont une capacité de transfert d'oxygène élevée et une réactivité élevée. L'addition de graphite dans l'alumine $\gamma$ n'améliore ni la surface spécifique ni la réactivité. Avec la pseudo-bohémite, on observe une décroissance de la capacité de transfert d'oxygène et l'agglomération du matériau pendant la phase de réduction. L'ajout de $\mathrm{MgO}$ conduit à une baisse de la réactivité en réduction. Avec l'alumine $\alpha$, la capacité de transfert est réduite. Les différences de réactivité peuvent être expliquées par les interactions entre $\mathrm{NiO}$ et le support, à partir d'analyses en réduction par température programmée. Les tests de réactivité conduits dans cette étude suggèrent que les supports à base de $\gamma-\mathrm{Al}_{2} \mathrm{O}_{3}$ et d'hydrotalcite sont les plus appropriés pour préparer les transporteurs d'oxygène contenant de l'oxyde de Nickel à haute concentration pour la combustion en boucle chimique.
\end{abstract}

\footnotetext{
Abstract - Effects of Support on the Performance of NiO-Based Oxygen Carriers - The performance of an oxygen carrier for Chemical Looping Combustion varies with the support material used. NiO oxygen carriers were prepared using 60 or $70 \mathrm{wt} \% \mathrm{NiO}$ and different raw support materials $\left(\gamma-\mathrm{Al}_{2} \mathrm{O}_{3}\right.$, pseudoboehmite, $\alpha-\mathrm{Al}_{2} \mathrm{O}_{3}, \gamma-\mathrm{Al}_{2} \mathrm{O}_{3}$ mixed with $\mathrm{MgO}$, hydrotalcite, $\mathrm{MgAl}_{2} \mathrm{O}_{4}$, and $\gamma-\mathrm{Al}_{2} \mathrm{O}_{3}$ with added graphite) by the mechanical mixing method. Reactivity tests were conducted using a thermogravimetric analyzer (TGA) at $950^{\circ} \mathrm{C}$. The oxygen carriers prepared using $\gamma-\mathrm{Al}_{2} \mathrm{O}_{3}, \gamma-\mathrm{Al}_{2} \mathrm{O}_{3}$ mixed with a small amount of $\mathrm{MgO}$, hydrotalcite, and $\mathrm{MgAl}_{2} \mathrm{O}_{4}$ showed high oxygen transfer capacity, high oxygen utilization, and a high oxygen transfer rate. Graphite addition to $\gamma-\mathrm{Al}_{2} \mathrm{O}_{3}$ did not increase the surface area or reactivity. The use of pseudoboehmite as a support led to a significant decrease in oxygen transfer capacity and severe agglomeration of the oxygen carriers during the redox reaction. The increase in $\mathrm{MgO}$
} 
content in the raw support materials decreased the reduction reactivity. The oxygen carriers prepared with $\alpha-\mathrm{Al}_{2} \mathrm{O}_{3}$ showed less oxygen transfer capacity than the other oxygen carriers. The differences in the reactivity according to the support type were explained by the relative strength of NiO-support interaction obtained from the temperature-programmed reduction analysis. The reactivity test results in this work indicate that $\gamma-\mathrm{Al}_{2} \mathrm{O}_{3}$ and hydrotalcite could be desirable raw support materials to prepare highly reactive $\mathrm{NiO}$ oxygen carriers with high $\mathrm{NiO}$ content.

\section{NOTATION}

\section{Symbol}

$X \quad$ Degree of conversion

$m \quad$ Mass of oxygen carrier $(\mathrm{g})$

$R_{\mathrm{O}} \quad$ Oxygen ratio

\section{Greek symbol}

$\omega$

Mass-based conversion

\section{Subscript \\ ox Fully oxidized state \\ red Fully reduced state}

\section{INTRODUCTION}

Chemical Looping Combustion (CLC) is an emerging technology to mitigate carbon emission from fossil fuel power plants without a thermal efficiency loss. A CLC process consists of two inter-connected fluidized-bed reactors operated at high temperatures. An oxygen carrier composed of metal oxides and support materials supplies the oxygen required for the combustion of fuels in a Fuel Reactor (FR) and it is regenerated by receiving oxygen from the air in an Air Reactor (AR) (Fig. 1). High reactivity for the complete combustion of fuels is one of the important factors in the development of oxygen carriers because the oxygen carrier inventory and oxygen carrier circulation rate can be reduced.

The oxides of $\mathrm{Ni}, \mathrm{Fe}, \mathrm{Cu}$ and $\mathrm{Mn}$ have been frequently tested as potential active phase metal oxides [1-10]. Among these metal oxides, $\mathrm{NiO}$ has been preferred as the most appropriate metal oxide for the combustion of Natural Gas (NG) due to its high reactivity with $\mathrm{NG}$ and high oxygen ratio compared with other metal oxides, though it is more expensive and complete fuel conversion of $\mathrm{CH}_{4}$ cannot be reached due to thermodynamic limitations. The metal oxides are supported on inorganic materials such as $\mathrm{Al}_{2} \mathrm{O}_{3}, \mathrm{ZrO}_{2}$, $\mathrm{TiO}_{2}$, YSZ, etc. The supports improve the physical properties such as mechanical strength, surface area and porosity and increase the reactivity of oxygen carriers by promoting the dispersion of metal oxides. The supports also help to maintain the chemical and physical stability of the oxygen carriers.
However, the oxygen transfer capacity of the oxygen carriers decreases with the increase in support content. Some supports strongly interact with the active phase metal oxides and reduce the reactivity. From thermodynamic analysis, Mattisson et al. [11] reported that the presence of $\mathrm{NiAl}_{2} \mathrm{O}_{4}$ results in low methane conversion $\left(<95.2 \%, T>900^{\circ} \mathrm{C}\right)$ to $\mathrm{CO}_{2}$ and $\mathrm{H}_{2} \mathrm{O}$ and increases the amounts of $\mathrm{CO}$ and $\mathrm{H}_{2}$ in the gas outlet of a FR, while the conversion was higher for $\mathrm{NiO}$ (>99\% for $T<900^{\circ} \mathrm{C}, 97.7 \%$ at $1200^{\circ} \mathrm{C}$ ). This means that increasing the amount of free $\mathrm{NiO}$ by reducing $\mathrm{NiO}$-support

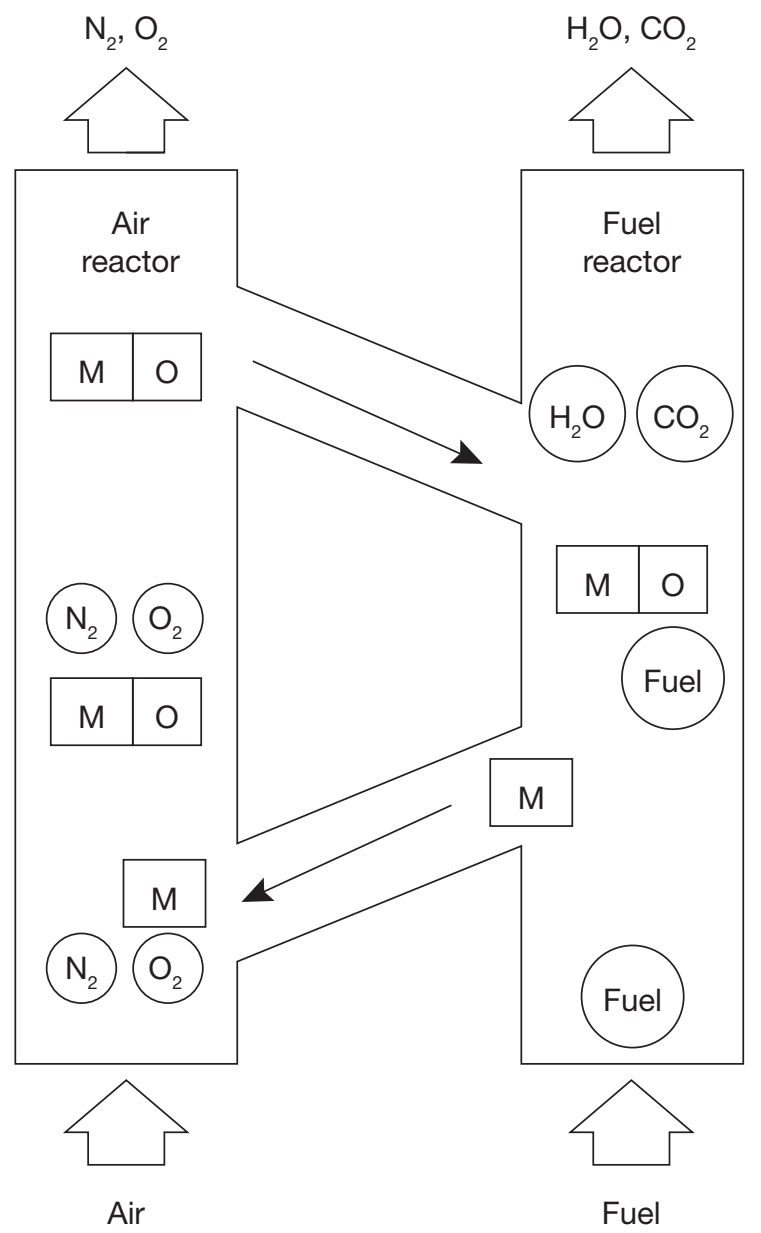

Figure 1

Schematic drawing of Chemical Looping Combustion process. M: metal; O: oxygen. 
interaction can lead to higher methane conversion to $\mathrm{CO}_{2}$ and $\mathrm{H}_{2} \mathrm{O}$. Therefore, appropriate support material should be selected according to the metal oxide type used. The $\mathrm{CH}_{4}$ conversion could also be enhanced by mixing the $\mathrm{NiO}$ with other metal oxides which do not have a restricted fuel conversion.

Several studies to screen the support materials for $\mathrm{Ni}$ are reported in the literature. Gayán et al. [7] used $\gamma-\mathrm{Al}_{2} \mathrm{O}_{3}, \alpha$ $\mathrm{Al}_{2} \mathrm{O}_{3}, \mathrm{MgAl}_{2} \mathrm{O}_{4}, \gamma-\mathrm{Al}_{2} \mathrm{O}_{3}$ precoated with $\mathrm{MgO}, \gamma-\mathrm{Al}_{2} \mathrm{O}_{3}$ precoated with $\mathrm{CaO}$, and $\mathrm{CaAl}_{2} \mathrm{O}_{4}$ as the raw support materials for the preparation of $\mathrm{NiO}$ oxygen carriers. They reported that the Ni-based oxygen carrier prepared on $\gamma-\mathrm{Al}_{2} \mathrm{O}_{3}$ showed low reactivity and low methane combustion selectivity to $\mathrm{CO}_{2}$ and $\mathrm{H}_{2} \mathrm{O}$ due to the formation of $\mathrm{NiAl}_{2} \mathrm{O}_{4}$ by the interaction between $\mathrm{NiO}$ and $\gamma-\mathrm{Al}_{2} \mathrm{O}_{3}$, while the Ni-based oxygen carriers prepared on $\alpha-\mathrm{Al}_{2} \mathrm{O}_{3}, \mathrm{MgAl}_{2} \mathrm{O}_{4}$ and $\mathrm{CaAl}_{2} \mathrm{O}_{4}$ showed high reactivity and high methane combustion selectivity to $\mathrm{CO}_{2}$ and $\mathrm{H}_{2} \mathrm{O}$ due to the decrease in the interaction between $\mathrm{NiO}$ and the supports. Their result was obtained for the maximum $38 \mathrm{wt} \% \mathrm{NiO}$. Ishida et al. [12] and Jin et al. [13] reported that an oxygen carrier with $60 \mathrm{wt} \% \mathrm{NiO}$ supported on $\mathrm{YSZ}$ or $\mathrm{NiAl}_{2} \mathrm{O}_{4}$ showed high reactivity with methane and high regenerability. Shulman et al. [14] used commercially available $\mathrm{NiO}, \alpha-\mathrm{Al}_{2} \mathrm{O}_{3}$ and $\mathrm{MgO}$ to make spray-dried oxygen carriers with $40 \mathrm{wt} \% \mathrm{NiO}$ supported on $\mathrm{NiAl}_{2} \mathrm{O}_{4}$, or $40 \mathrm{wt} \% \mathrm{NiO}$ supported on $\mathrm{NiAl}_{2} \mathrm{O}_{4} / \mathrm{MgAl}_{2} \mathrm{O}_{4}$. The structurally stable raw support materials such as YSZ, $\mathrm{NiAl}_{2} \mathrm{O}_{4}$ and $\mathrm{MgAl}_{2} \mathrm{O}_{4}$ are commonly expensive and require higher calcination temperatures to obtain oxygen carriers with sufficient mechanical strength for an application to the fluidized-bed processes.

Although there have been lots of studies on the performance of $\mathrm{NiO}$ oxygen carriers, the performance of those with a $\mathrm{NiO}$ content of above $60 \mathrm{wt} \%$ supported on structurally less stable raw support materials such as pseudoboehmite, $\gamma-\mathrm{Al}_{2} \mathrm{O}_{3}$ or hydrotalcite is not wellknown. Pseudoboehmite $(\mathrm{AlOOH})$ is poorly crystalline boehmite. It is widely used as a binder material for the preparation of catalysts and solid sorbents. With the temperature increase, it changes to $\gamma-\mathrm{Al}_{2} \mathrm{O}_{3}, \theta-\mathrm{Al}_{2} \mathrm{O}_{3}$, and then $\alpha-\mathrm{Al}_{2} \mathrm{O}_{3}$, while losing $\mathrm{H}_{2} \mathrm{O}$. Hydrotalcite or Layered Double Hydroxide (LDH) is a layered material with positively charged layers and charge-balancing anions located in the interlayer region. The general form of hydrotalcite is $\left[\mathrm{M}^{2+}{ }_{1-x} \mathrm{M}^{3+}{ }_{x}(\mathrm{OH})_{2}\right] \mathrm{A}^{n-}{ }_{x / n}$, where $\mathrm{M}^{2+}$ and $\mathrm{M}^{3+}$ are $\mathrm{Mg}^{2+}, \mathrm{Ca}^{2+}$, $\mathrm{Ni}^{2+}$, etc. and $\mathrm{Al}^{3+}, \mathrm{V}^{3+}, \mathrm{Fe}^{3+}$, etc., and $\mathrm{A}^{n-}$ is generic anions compensating charge $\left(\mathrm{CO}_{2}{ }^{2-}, \mathrm{Cl}^{-}, \mathrm{OH}^{-}, \mathrm{SO}_{4}{ }^{2-}\right.$, etc. $)$. When the temperature increases, hydrotalcite is thermally decomposed and evolves gases such as $\mathrm{H}_{2} \mathrm{O}$ and $\mathrm{CO}_{2}$, and finally yields a mixture of divalent metal oxide $\left(\mathrm{M}^{2+} \mathrm{O}\right)$ and mixed metal spinel $\left(\mathrm{M}^{2+} \mathrm{M}^{3+} \mathrm{O}_{4}\right)[15,16]$.

In this study, $\mathrm{NiO}$ oxygen carriers designed with high $\mathrm{NiO}$ content and various support materials $\left(\gamma-\mathrm{Al}_{2} \mathrm{O}_{3}\right.$, pseudoboehmite, $\alpha-\mathrm{Al}_{2} \mathrm{O}_{3}, \gamma-\mathrm{Al}_{2} \mathrm{O}_{3}$ mixed with $\mathrm{MgO}$, hydro- talcite, $\mathrm{MgAl}_{2} \mathrm{O}_{4}$, and $\gamma-\mathrm{Al}_{2} \mathrm{O}_{3}$ with added graphite) were prepared by the mechanical mixing method to investigate the effect of each support on the reactivity of oxygen carriers with high $\mathrm{NiO}$ content above 60 wt $\% . \quad \gamma-\mathrm{Al}_{2} \mathrm{O}_{3}$, pseudoboehmite and hydrotalcite are structurally less stable than $\alpha-\mathrm{Al}_{2} \mathrm{O}_{3}, \mathrm{MgAl}_{2} \mathrm{O}_{4}, \mathrm{YSZ}$ and $\mathrm{NiAl}_{2} \mathrm{O}_{4}$. Although strong interactions between $\mathrm{NiO}$ and these structurally less stable raw support materials may be formed during calcination, it was assumed that the interaction could be reduced at a high $\mathrm{NiO}$ content because a lower number of support molecules would interact with a $\mathrm{NiO}$ molecule compared with a low $\mathrm{NiO}$ content. Furthermore, the surface area of these structurally less stable raw support materials is much higher than that of stable raw support materials. Therefore, performance improvement by a higher surface area after calcination was expected. The positive effects on the methane conversion caused by adding small amounts of $\mathrm{MgO}$ to $\alpha-\mathrm{Al}_{2} \mathrm{O}_{3}$ for $\mathrm{NiO}$ oxygen carriers have been reported in the literature $[14,17$ 20]. This work investigated the effect of $\mathrm{MgO}$ addition on the reactivity of a $\mathrm{NiO}$ oxygen carrier prepared with $\gamma-\mathrm{Al}_{2} \mathrm{O}_{3}$. Hydrotalcite $(\mathrm{Mg}-\mathrm{Al} \mathrm{LDH})$ was selected as a new raw support material containing a $\mathrm{Mg}$ component. $\alpha-\mathrm{Al}_{2} \mathrm{O}_{3}$ and $\mathrm{MgAl}_{2} \mathrm{O}_{4}$ were tested for comparison purposes. Thermogravimetric analyzer (TGA) reactivity tests and TemperatureProgrammed Reduction (TPR) were carried out to compare the oxygen transfer performance of the prepared oxygen carriers.

\section{EXPERIMENTAL}

\subsection{Preparation of Oxygen Carriers}

Oxygen carriers with high $\mathrm{NiO}$ content were prepared by the mechanical mixing method. Commercially available raw materials in powder form were used to prepare the oxygen carriers. The property data on the raw materials used in this work are given in Table 1 . The $\mathrm{NiO}$ content was 60 or $70 \mathrm{wt} \% \cdot \gamma-\mathrm{Al}_{2} \mathrm{O}_{3}$, pseudoboehmite, $\gamma-\mathrm{Al}_{2} \mathrm{O}_{3}$ mixed with $\mathrm{MgO}$, and hydrotalcite $(\mathrm{Mg}-\mathrm{Al} \mathrm{LDH})$ were used as structurally less stable raw support materials. $\gamma-\mathrm{Al}_{2} \mathrm{O}_{3}$ mixed with additional $10 \mathrm{wt} \%$ graphite was tested to investigate if the reactivity could be improved by increasing the surface area of the oxygen carrier after burning out the graphite during calcination. The compositions of the oxygen carriers prepared in this work are presented in Table 2.

Raw materials were mechanically well mixed in pure water. The water content (usually 50 to $70 \mathrm{wt} \%$ ) in the slurry was adjusted to make extrudable slurry. The slurry was extruded in a cylindrical form with 2-mm diameter and dried at $120^{\circ} \mathrm{C}$. After calcination at $1100^{\circ} \mathrm{C}$ for $5 \mathrm{~h}$ under an ambient air environment in a muffle oven, the oxygen carriers were crushed to obtain particles, with the particle size ranging from 106 to $150 \mu \mathrm{m}$. 
TABLE 1

Physical properties of raw materials used in oxygen carrier preparation

\begin{tabular}{l|c|c}
\hline Raw material & $\begin{array}{c}\text { Particle size } \\
(\mu \mathrm{m})\end{array}$ & $\begin{array}{c}\text { Surface area } \\
\left(\mathrm{m}^{2} / \mathrm{g}\right)\end{array}$ \\
\hline $\mathrm{NiO}$ & $0.6\left(\mathrm{~d}_{50}\right), 1.6(\max )$. & \\
\hline$\gamma-\mathrm{Al}_{2} \mathrm{O}_{3}$ & $5.6\left(\mathrm{~d}_{50}\right), 12.9\left(\mathrm{~d}_{90}\right)$ & 158 \\
\hline Pseudoboehmite & $<25(78 \%),<45(98 \%)$ & 234 \\
\hline$\alpha-\mathrm{Al}_{2} \mathrm{O}_{3}$ & $0.5\left(\mathrm{~d}_{50}\right), 23.2\left(\mathrm{~d}_{90}\right)$ & 9.1 \\
\hline $\mathrm{MgO}$ & $3-8(\mathrm{avg})$. & 45 \\
\hline $\mathrm{Hydrotalcite}$ & $<45(51 \%),<90(92 \%)$ & 250 \\
\hline $\mathrm{MgAl}_{2} \mathrm{O}_{4}$ & $1-5$ & 0.9 \\
\hline Graphite & $2.8\left(\mathrm{~d}_{50}\right), 5.0\left(\mathrm{~d}_{90}\right)$ & 2.5 \\
\hline
\end{tabular}

The prepared oxygen carriers are designated by abbreviations implying a material name and a material content. $\mathrm{N}$, GA, B, C, AA, M, HT and MA in the names of the oxygen carriers mean $\mathrm{NiO}, \gamma-\mathrm{Al}_{2} \mathrm{O}_{3}$, pseudoboehmite, graphite (carbon), $\alpha-\mathrm{Al}_{2} \mathrm{O}_{3}, \mathrm{MgO}$, hydrotalcite and $\mathrm{MgAl}_{2} \mathrm{O}_{4}$, respectively. For example, N70-GA-M8 means the oxygen carrier prepared with $70 \mathrm{wt} \% \mathrm{NiO}$ and $\gamma-\mathrm{Al}_{2} \mathrm{O}_{3}$ mixed with $8 \mathrm{wt} \% \mathrm{MgO}$.

\subsection{Reactivity Investigation in a TGA}

The oxygen transfer capacity and reaction rate were measured with a TGA (Thermo Cahn, TherMax500) using 10 vol\% methane in $\mathrm{CO}_{2}$ and air as a reducing gas and an oxidizing gas, respectively, at the reaction temperature of $950^{\circ} \mathrm{C}$ and at ambient pressure. Approximately $20 \mathrm{mg}$ of sample was placed on the alumina crucible and heated to the reaction temperature. The flow rate of the gases was $2.5 \times 10^{-6} \mathrm{~m}^{3} / \mathrm{s}$ on the basis of $0^{\circ} \mathrm{C}$ and $1 \mathrm{~atm}$, at which external mass-transfer-limited reaction conditions could be avoided. An inert gas, $\mathrm{N}_{2}$, was fed into the reactor at the same flow rate after each reduction and oxidation period to prevent direct contact of the fuel gases and air. The weight and furnace temperature data were continuously recorded every second by a data acquisition unit. At least five cycles of reduction and oxidation were performed in the TGA for each oxygen carrier.

TABLE 2

Properties of oxygen carriers supported on different support materials

\begin{tabular}{|c|c|c|c|c|}
\hline \multirow{2}{*}{ Oxygen carrier } & \multicolumn{2}{|c|}{$\begin{array}{c}\text { Composition } \\
\text { (solid raw material basis) }\end{array}$} & \multirow{2}{*}{$\begin{array}{c}\text { BET } \\
\text { surface area** } \\
\left(\mathrm{m}^{2} / \mathrm{g}\right)\end{array}$} & \multirow{2}{*}{$\mathrm{XRD} * *$} \\
\hline & $\mathrm{NiO}(\mathrm{wt} \%)$ & Supports (wt $\%$ ) & & \\
\hline N60-GA & 60 & $\gamma-\mathrm{Al}_{2} \mathrm{O}_{3}(40)$ & 6.6 & \\
\hline N70-GA & 70 & $\gamma-\mathrm{Al}_{2} \mathrm{O}_{3}(30)$ & 6.6 & $\alpha-\mathrm{Al}_{2} \mathrm{O}_{3}, \mathrm{NiO}, \mathrm{NiAl}_{2} \mathrm{O}_{4}$ \\
\hline N60-B & 60 & Pseudoboehmite (40) & 5.1 & $\alpha-\mathrm{Al}_{2} \mathrm{O}_{3}, \mathrm{NiO}, \mathrm{NiAl}_{2} \mathrm{O}_{4}$ \\
\hline N70-B & 70 & Pseudoboehmite (30) & 4.1 & \\
\hline N60-GA-C & 60 & $\gamma-\mathrm{Al}_{2} \mathrm{O}_{3}(40)$, graphite* & 6.9 & \\
\hline N70-GA-C & 70 & $\gamma-\mathrm{Al}_{2} \mathrm{O}_{3}(30)$, graphite* & 6.0 & \\
\hline N60-AA & 60 & $\alpha-\mathrm{Al}_{2} \mathrm{O}_{3}(40)$ & 2.6 & $\alpha-\mathrm{Al}_{2} \mathrm{O}_{3}, \mathrm{NiO}, \mathrm{NiAl}_{2} \mathrm{O}_{4}$ \\
\hline N70-AA & 70 & $\alpha-\mathrm{Al}_{2} \mathrm{O}_{3}(30)$ & 2.9 & \\
\hline N60-GA-M5 & 60 & $\gamma-\mathrm{Al}_{2} \mathrm{O}_{3}(35), \mathrm{MgO}(5)$ & 9.9 & \\
\hline N60-GA-M10 & 60 & $\gamma-\mathrm{Al}_{2} \mathrm{O}_{3}(30), \mathrm{MgO}(10)$ & 10.9 & $\alpha-\mathrm{Al}_{2} \mathrm{O}_{3}, \mathrm{NiO}, \mathrm{NiAl}_{2} \mathrm{O}_{4}, \mathrm{MgAl}_{2} \mathrm{O}_{4}$ \\
\hline N70-GA-M4 & 70 & $\gamma-\mathrm{Al}_{2} \mathrm{O}_{3}(26), \mathrm{MgO}(4)$ & 7.6 & \\
\hline N70-GA-M8 & 70 & $\gamma-\mathrm{Al}_{2} \mathrm{O}_{3}(22), \mathrm{MgO}(8)$ & 8.7 & \\
\hline N60-HT & 60 & Hydrotalcite (40) & 6.2 & $\mathrm{NiO}, \mathrm{NiAl}_{2} \mathrm{O}_{4}, \mathrm{MgAl}_{2} \mathrm{O}_{4}$ \\
\hline N70-HT & 70 & Hydrotalcite (30) & 5.5 & \\
\hline N60-MA & 60 & $\mathrm{MgAl}_{2} \mathrm{O}_{4}(40)$ & 1.2 & $\mathrm{NiO}, \mathrm{MgAl}_{2} \mathrm{O}_{4}$ \\
\hline N70-MA & 70 & $\mathrm{MgAl}_{2} \mathrm{O}_{4}(30)$ & 1.5 & \\
\hline
\end{tabular}

* Graphite was additionally added at $10 \mathrm{wt} \%$.** Surface area and XRD analysis were conducted for the oxygen carriers calcined at $1100^{\circ} \mathrm{C}$. 
When the reaction was very slow, reaction gases were changed to $\mathrm{N}_{2}$ after 30 minute reaction. TPR tests were performed with the same TGA up to a temperature of $1000^{\circ} \mathrm{C}$ (a temperature ramping rate of $5^{\circ} \mathrm{C} / \mathrm{min}$ ) using $10 \mathrm{vol} \% \mathrm{H}_{2}$ in $\mathrm{Ar}$ to investigate the interaction between $\mathrm{NiO}$ and supports and the reaction temperature zone.

The reactivity of each oxygen carrier at the fifth cycle was analyzed in terms of oxygen transfer capacity and oxygen transfer rate. Oxygen transfer capacity is the maximum percentage of mass change by oxygen transfer under the given experimental conditions, and it is calculated on the basis of the mass of the fresh oxygen carrier in its fully-oxidized state. The oxygen transfer rate is expressed as the mol of transferred oxygen per unit gram of oxygen carrier per unit time (mol O/god $/ \mathrm{s})$. The degree of conversion, $X$, of a metal oxide is defined as:

$$
X=\frac{m_{o x}-m}{m_{o x}-m_{r e d}}
$$

where $m$ is the instantaneous mass of an oxygen carrier measured by the TGA, and $m_{o x}$ and $m_{r e d}$ are the theoretical masses of the oxygen carrier in its fully-oxidized and fullyreduced state, respectively, when it is assumed that all oxygen in the $\mathrm{NiO}$ which was added as a raw material is transferable. The $m_{o x}$ is equal to the mass of the fresh oxygen carrier in its fully-oxidized state. The denominator of Equation (1), the weight difference between $m_{o x}$ and $m_{\text {red }}$, is the theoretical maximum amount of oxygen that can be transferred to the fuel. Oxygen utilization is percentage of the degree of conversion during the reduction reaction. A mass-based conversion, $\omega$, was used to compare the mass change as a function of time. It is defined as

$$
\omega=\frac{m}{m_{o x}}=R_{\mathrm{O}}(X-1)
$$

The oxygen ratio $\left(R_{\mathrm{O}}\right)$, the theoretical maximum mass fraction of oxygen that can be transferred to the fuel, of pure $\mathrm{NiO}$ is 0.214 . Therefore, the theoretical mass-based conversions of the prepared samples in their fully-reduced state are 0.87 and 0.85 for 60 and $70 \mathrm{wt} \% \mathrm{NiO}$ content, respectively, on a dry solid raw material basis.

\section{RESULTS AND DISCUSSION}

\subsection{Comparison of Oxygen Transfer Capacity, Oxygen Utilization and Oxygen Transfer Rate}

The oxygen transfer capacities of the prepared $\mathrm{NiO}$ oxygen carriers are compared in Figure 2 as a function of the number of cycles. N60-HT and N70-HT showed the highest oxygen transfer capacities, 14.2 and $15.9 \mathrm{wt} \%$, respectively. In the temperature-programmed desorption test for the raw hydro-

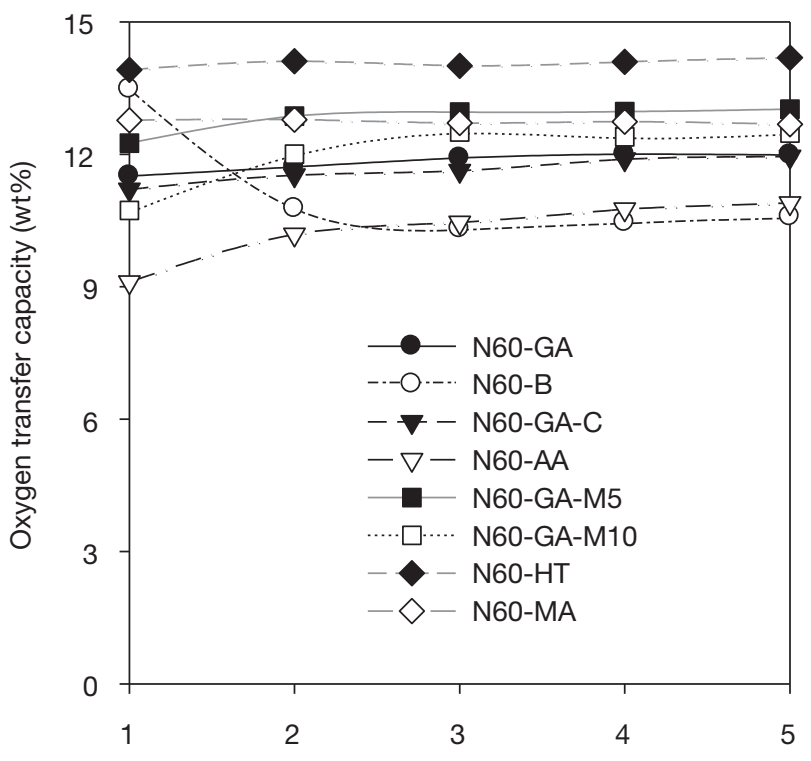

a)

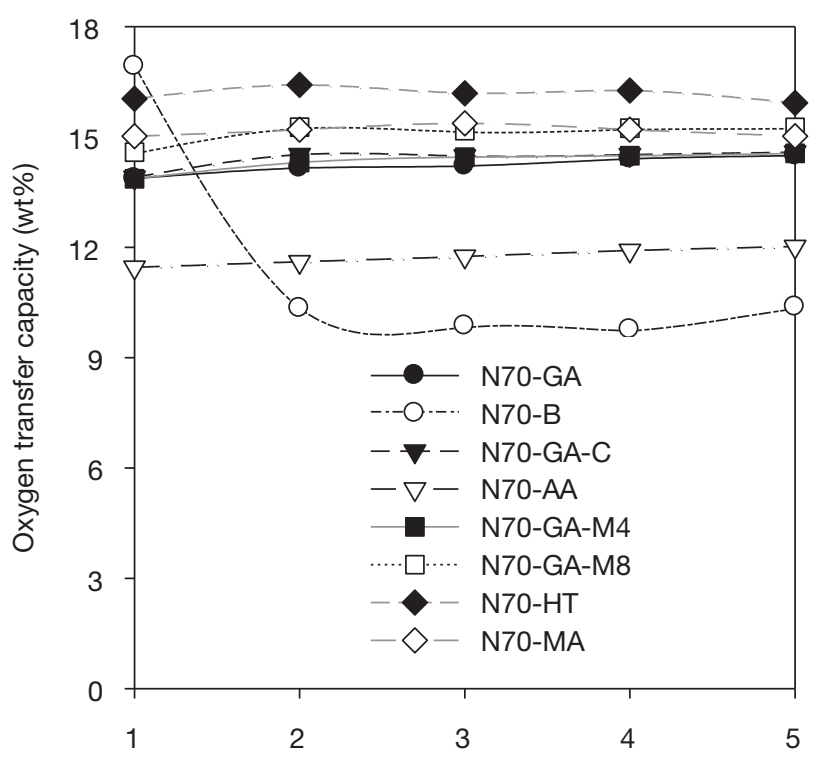

b)

Number of cycles

Figure 2

Oxygen transfer capacities of the oxygen carriers prepared using a) $60 \mathrm{wt} \% \mathrm{NiO}$ and different raw support materials and b) $70 \mathrm{wt} \% \mathrm{NiO}$ and different raw support materials.

talcite from room temperature to $1000^{\circ} \mathrm{C}$, weight loss of about $35 \mathrm{wt} \%$, which was caused by dehydroxylation and decarbonation, was observed. This indicates that the $\mathrm{NiO}$ content of the oxygen carriers prepared using hydrotalcite would be increased after calcination compared with the initial $\mathrm{NiO}$ content in the raw materials. The oxygen transfer capacities of N60-HT and N70-HT are higher than expected, which could be ascribed to this increased $\mathrm{NiO}$ content. 
Oxygen carriers prepared with $\gamma-\mathrm{Al}_{2} \mathrm{O}_{3}, \gamma-\mathrm{Al}_{2} \mathrm{O}_{3}$ mixed with $\mathrm{MgO}$, and $\mathrm{MgAl}_{2} \mathrm{O}_{4}$ also had high oxygen transfer capacities, above 12.0 and $14.5 \mathrm{wt} \%$ for 60 and $70 \mathrm{wt} \% \mathrm{NiO}$ content, respectively. This means that more than 93 and $96 \%$ of the total oxygen in the 60 and $70 \mathrm{wt} \% \mathrm{NiO}$, respectively, were transferred to the fuel. The addition of graphite to $\gamma$ $\mathrm{Al}_{2} \mathrm{O}_{3}$-based oxygen carriers did not affect their oxygen transfer capacity. When $\gamma-\mathrm{Al}_{2} \mathrm{O}_{3}$ mixed with $\mathrm{MgO}$ was used as a raw support material, the oxygen transfer capacity slightly increased. N60-AA and N70-AA showed relatively low oxygen transfer capacity compared with that of the oxygen carriers prepared with other raw support materials. This was an unexpected result because a stable support has been known to reduce the interaction between the metal oxide and support and increase oxygen transfer performance.

The oxygen transfer capacity of N60-B and N70-B decreased significantly from the second cycle and these oxygen carriers were not ever fully regenerated to the initial oxidation state after 30 minutes oxidation. This seems to be due to the sintering of $\mathrm{NiO}$ supported on pseudoboehmite during the redox cycle. After redox cycle tests, severe agglomeration was observed. The $\mathrm{H}_{2}$-TPR analysis for the fresh N60-B and N60-B after cyclic redox tests showed that the onset temperature of reduction was lowered a little and the total weight loss and the weight loss above $700^{\circ} \mathrm{C}$ were apparently reduced after cyclic redox tests (Fig. 3). X-Ray Diffraction (XRD) analysis for both fresh and cycle-tested N60-B showed that there was no tendency to $\mathrm{NiAl}_{2} \mathrm{O}_{4}$ increase after cyclic redox tests, as shown in Figure 4. On the basis of TPR and XRD

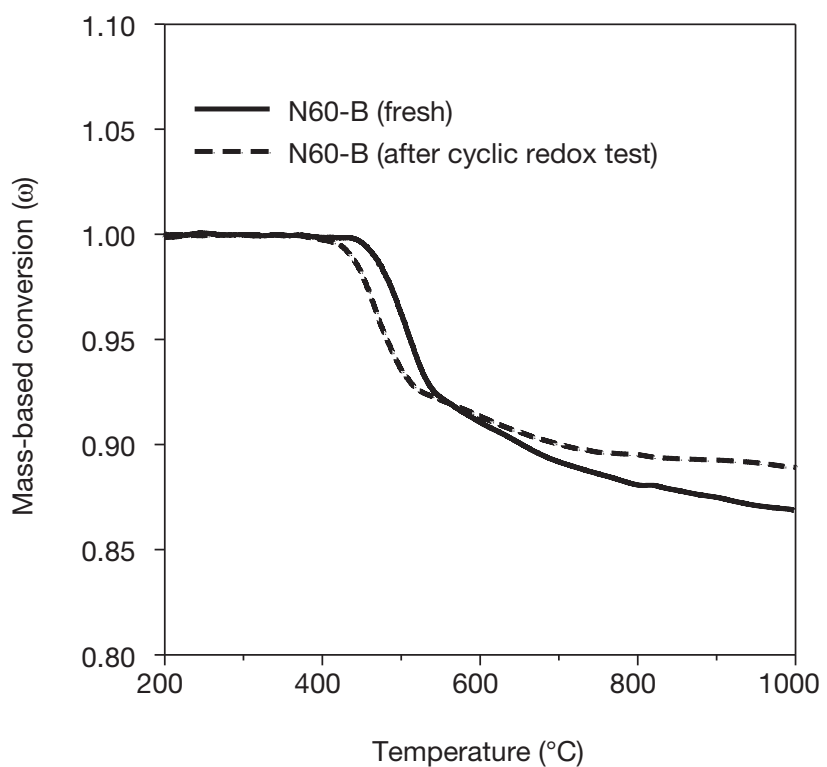

Figure 3

$\mathrm{H}_{2}$-TPR of the $\mathrm{NiO}$ oxygen carrier prepared using pseudoboehmite as a raw support material.
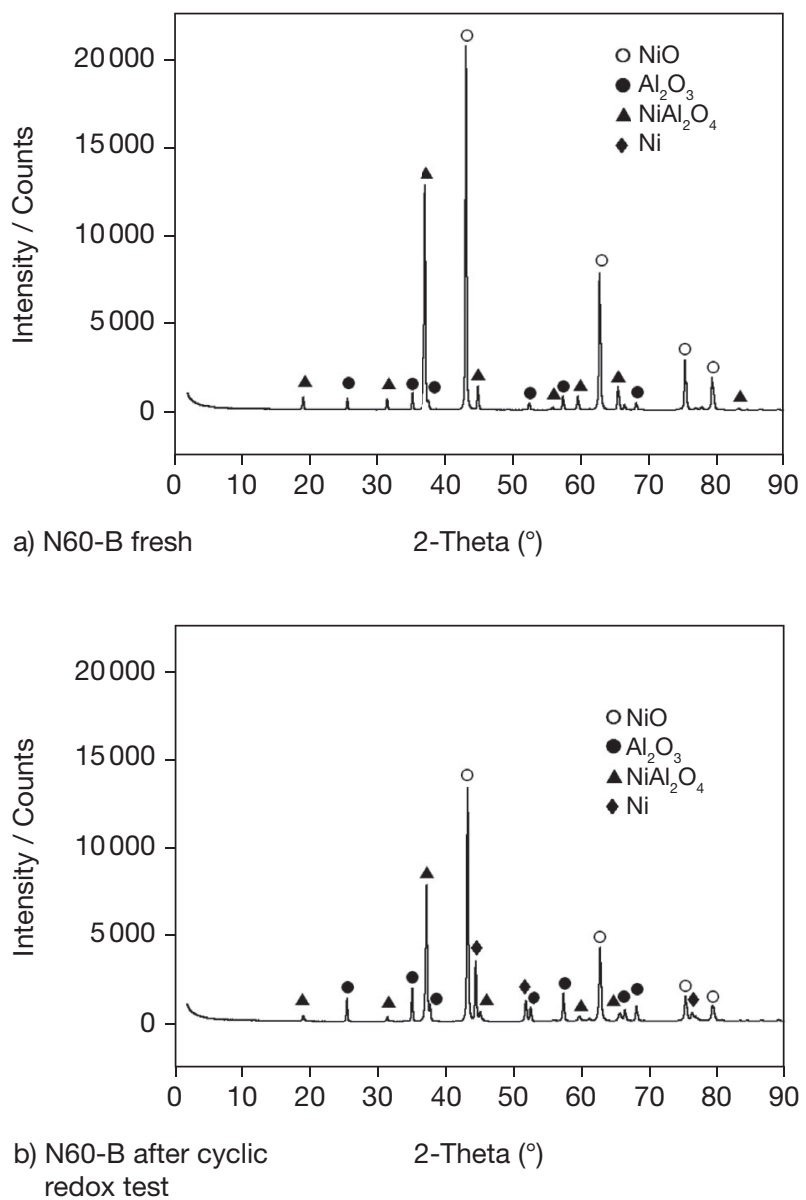

Figure 4

XRD results of a) fresh sample and b) the sample after cyclic redox tests at $950^{\circ} \mathrm{C}$ for the $\mathrm{NiO}$ oxygen carrier prepared using pseudoboehmite as a raw support material.

analysis, it can be concluded that the low reactivity of the $\mathrm{NiO}$ oxygen carrier prepared using pseudoboehmite was caused by sintering of $\mathrm{NiO}$ during the cyclic redox reaction. This means that the use of pseudoboehmite only as a support is not suitable.

Mass-based conversion changes as a function of the reaction time in the fuel reactor and the air reactor are presented in Figures 5 and 6. N60-GA and N70-GA showed relatively fast reduction and oxidation. There was no apparent improvement in the reaction rate by graphite addition, which was anticipated from the result of the graphite addition not leading to the expected increase in the surface area, as shown in Table 2. N60-B and N70-B reacted very slowly in both reduction and oxidation due to the sintering of $\mathrm{NiO}$, as explained above. Oxygen carriers containing a Mg component are reported to have the effects of enhancing the fuel combustion efficiency and reducing the agglomeration 

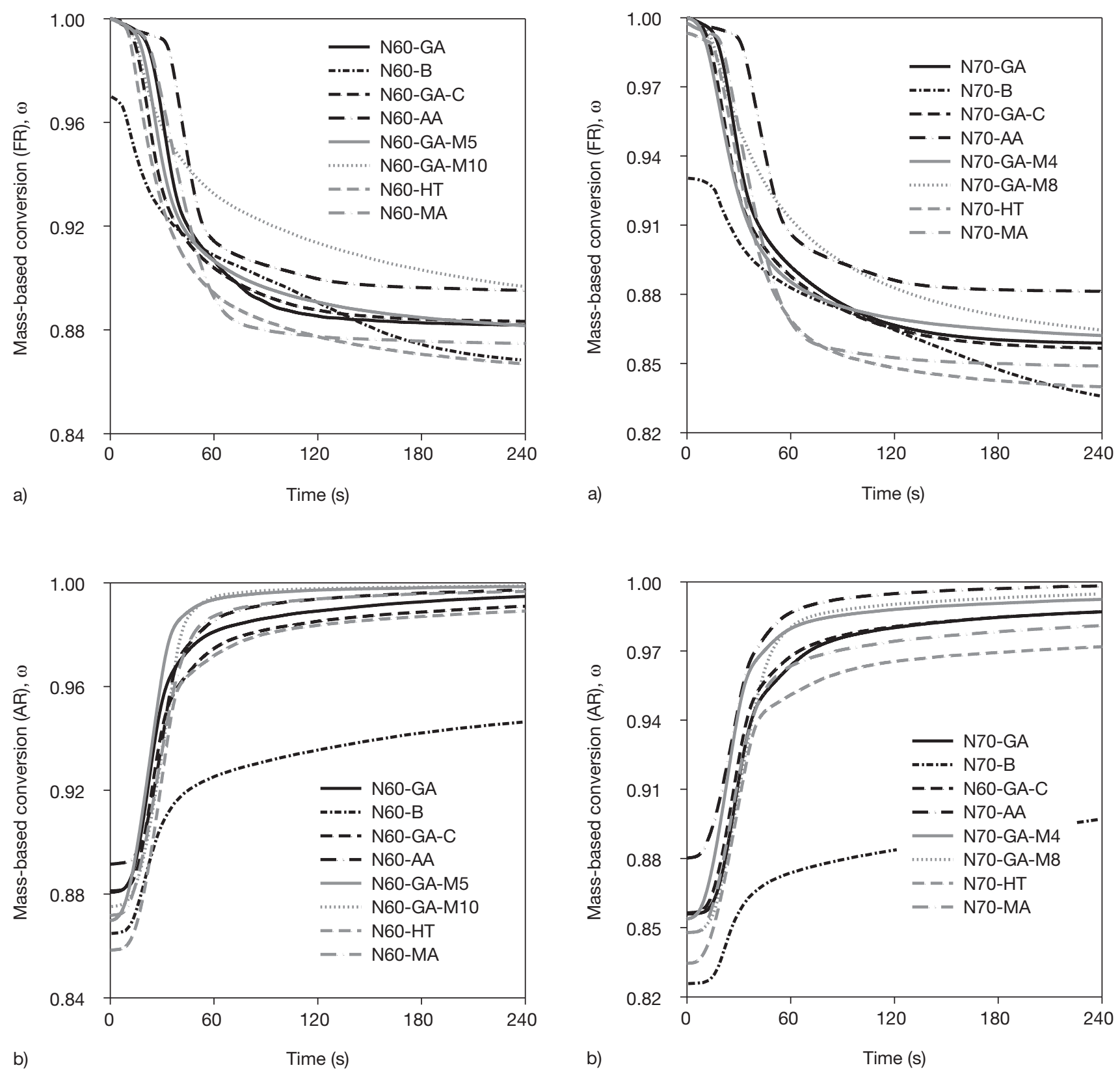

Figure 5

Mass-based conversion as a function of reaction time in a) the Fuel Reactor and b) the Air Reactor for the oxygen carriers prepared using $60 \mathrm{wt} \% \mathrm{NiO}$ and different raw support materials.

Figure 6

Mass-based conversion as a function of reaction time in a) the Fuel Reactor and b) the Air Reactor for the oxygen carriers prepared using $70 \mathrm{wt} \% \mathrm{NiO}$ and different raw support materials.

between particles [18, 21]. In this work, $\mathrm{Mg}$ was added using three different raw materials, $\mathrm{MgO}, \mathrm{MgAl}_{2} \mathrm{O}_{4}$ and hydrotalcite. When a small amount of $\mathrm{MgO}$ ( 4 and $5 \mathrm{wt} \%$ for 60 and $70 \mathrm{wt} \% \mathrm{NiO}$ content, respectively) was mixed with $\gamma-\mathrm{Al}_{2} \mathrm{O}_{3}$, the reactivity slightly increased. However, when the $\mathrm{MgO}$ content increased to 8 and $10 \mathrm{wt} \%$ for 60 and $70 \mathrm{wt} \% \mathrm{NiO}$ content, respectively, the reduction slowed down signifi- cantly, while the oxidation was faster than that of the other oxygen carriers. On the contrary, oxygen carriers prepared using $\mathrm{MgAl}_{2} \mathrm{O}_{4}$ and hydrotalcite showed relatively fast reduction and slow oxidation. Oxygen utilization changes of the oxygen carriers during reduction are presented as a function of reaction time in Figure 7. One minute after the beginning of the reduction, the oxygen utilization of N60-HT, 


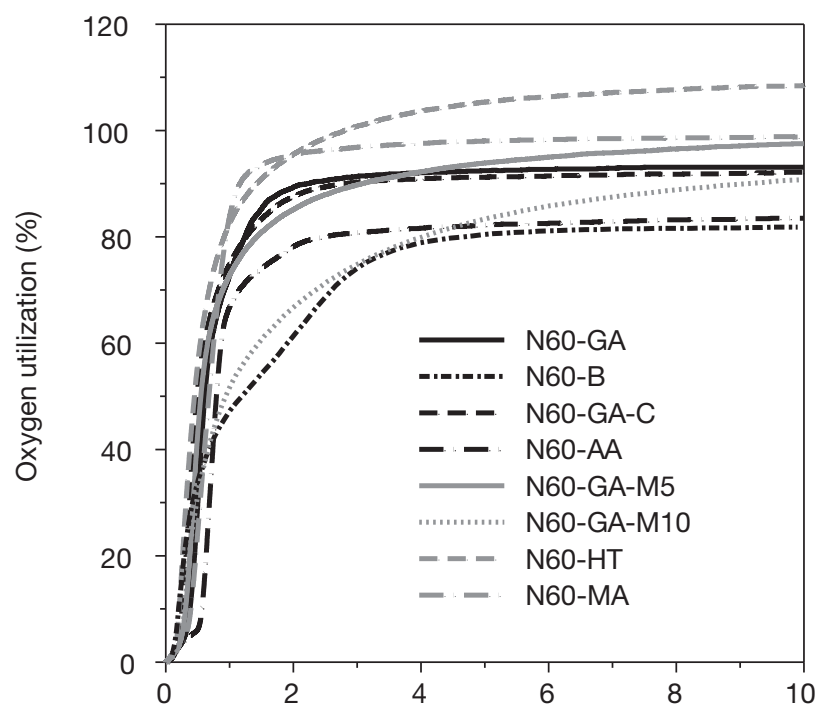

a)

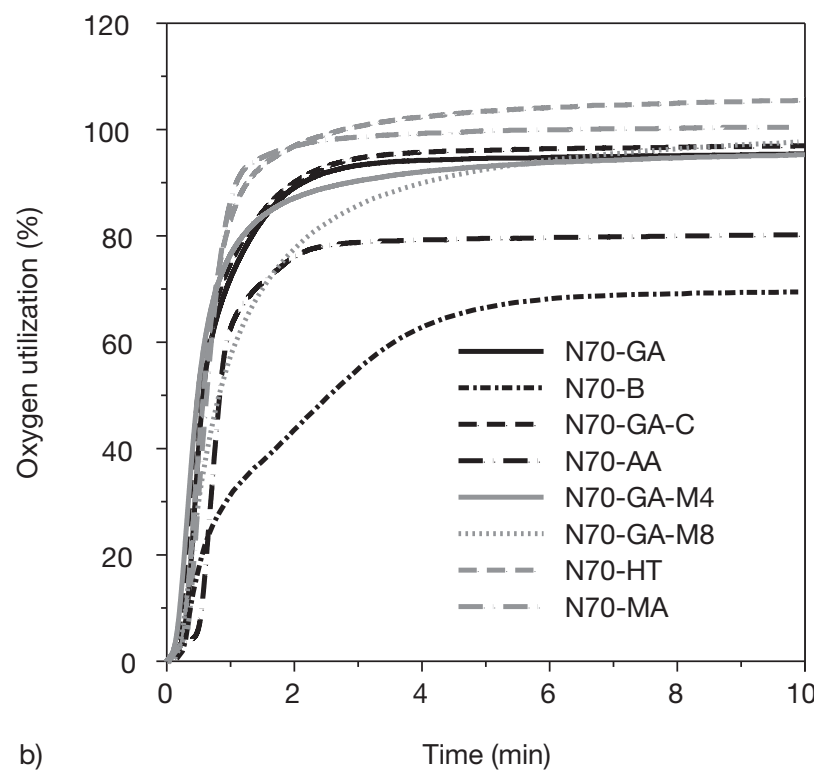

Figure 7

Oxygen utilization as a function of reaction time during reduction for the oxygen carriers prepared using (a) $60 \mathrm{wt} \%$ $\mathrm{NiO}$ and different raw support materials and (b) $70 \mathrm{wt} \% \mathrm{NiO}$ and different raw support materials.

N70-HT, N60-MA and N70-MA was over 80\% and the oxygen utilization of N60-GA, N70-GA, N60-GA-C, N70GA-C, N60-GA-M5, and N70-GA-M4 was over 70\%. Oxygen carriers supported on pseudoboehmite, $\alpha-\mathrm{Al}_{2} \mathrm{O}_{3}$ and $\gamma-\mathrm{Al}_{2} \mathrm{O}_{3}$ mixed with a large amount of $\mathrm{MgO}$ showed low oxygen utilization.
Oxygen transfer rate changes as a function of the degree of conversion for reduction and oxidation are presented in Figures 8 and 9. In an actual CLC process, an oxygen carrier circulates between the air reactor and the fuel reactor in a partially reduced state. The difference in degree of conversion between the air reactor and the fuel reactor is usually under 0.2. Therefore, it is important to circulate the oxygen carrier near the degree of conversion at which the highest reaction rate can be obtained. The highest reaction rate appeared in the degree of conversion $(X)$ between 0.3 and 0.6 for reduction and between 0.5 and 0.8 for oxidation. In these ranges of degree of conversion, oxygen carriers prepared using $\gamma-\mathrm{Al}_{2} \mathrm{O}_{3}, \gamma-\mathrm{Al}_{2} \mathrm{O}_{3}$ mixed with a small amount of $\mathrm{MgO}$, and hydrotalcite showed a high reaction rate at both reduction and oxidation and at both 60 and $70 \mathrm{wt} \% \mathrm{NiO}$ content. Oxygen carriers supported on pseudoboehmite and $\gamma-\mathrm{Al}_{2} \mathrm{O}_{3}$ mixed with a large amount of $\mathrm{MgO}$ showed a very low oxygen transfer rate in the entire range of degree of conversion.

$\mathrm{NiO}$ oxygen carriers supported on $\gamma-\mathrm{Al}_{2} \mathrm{O}_{3}$ and calcined at $1000-1100^{\circ} \mathrm{C}$ [7] were described to have low reactivity and low oxygen utilization as a result of the strong interaction between the $\mathrm{NiO}$ and the support material. However, the reactivity analysis in this work showed that a $\mathrm{NiO}$ oxygen carrier supported on $\gamma-\mathrm{Al}_{2} \mathrm{O}_{3}$ also had high reactivity when a high $\mathrm{NiO}$ content was used although $\mathrm{NiAl}_{2} \mathrm{O}_{4}$ was formed by the NiO-support interaction during calcination as shown in the XRD analysis results (Tab. 2),$\gamma-\mathrm{Al}_{2} \mathrm{O}_{3}$ mixed with a small amount of $\mathrm{MgO}$ and hydrotalcite appeared to be also good supports for the preparation of highly reactive oxygen carriers with a high $\mathrm{NiO}$ content. To clarify the effect of the use of high $\mathrm{NiO}$ content, $\mathrm{NiO}$ oxygen carriers with 22 and $42 \mathrm{wt} \% \mathrm{NiO}$ were prepared using $\gamma-\mathrm{Al}_{2} \mathrm{O}_{3}$ as a support, and N70-GA was calcined at $1400^{\circ} \mathrm{C} . \mathrm{H}_{2}$-TPR analysis and redox cycle tests were conducted for these oxygen carriers. As shown in Figure 10, a large amount of oxygen in the oxygen carriers prepared with 22 and $42 \mathrm{wt} \% \mathrm{NiO}$ was not transferred to the fuel until the temperature reached $900^{\circ} \mathrm{C}$. The portions of the unreacted oxygen in the total oxygen until $900^{\circ} \mathrm{C}$ were about $60,42,19$, and $4.6 \%$ for the oxygen carriers with $22,42,60$, and $70 \mathrm{wt} \% \mathrm{NiO}$ content, respectively. This indicates that the interaction between $\mathrm{NiO}$ and the support was reduced at a high $\mathrm{NiO}$ content. N70-GA calcined at $1400^{\circ} \mathrm{C}$ transferred a smaller amount of oxygen than N70GA calcined at $1100^{\circ} \mathrm{C}$. This also indicates that $\mathrm{Al}_{2} \mathrm{O}_{3}$ in the N70-GA calcined at $1100^{\circ} \mathrm{C}$ did not completely interact with $\mathrm{NiO}$ to form stable $\mathrm{NiAl}_{2} \mathrm{O}_{4}$. XRD analysis also showed that alumina in the oxygen carriers prepared using $\gamma-\mathrm{Al}_{2} \mathrm{O}_{3}$ still remained as the $\alpha-\mathrm{Al}_{2} \mathrm{O}_{3}$ form without being transformed completely into $\mathrm{NiAl}_{2} \mathrm{O}_{4}$. The result of cyclic redox tests at $950^{\circ} \mathrm{C}$ for these oxygen carriers confirms the effect of the use of high $\mathrm{NiO}$ content (Fig. 11). The oxygen utilization of N22-GA was only $27 \%$, while that of N70-GA was $96 \%$. This implies that the use of high $\mathrm{NiO}$ content could increase oxygen utilization. N70-GA calcined at $1400^{\circ} \mathrm{C}$ was reduced 


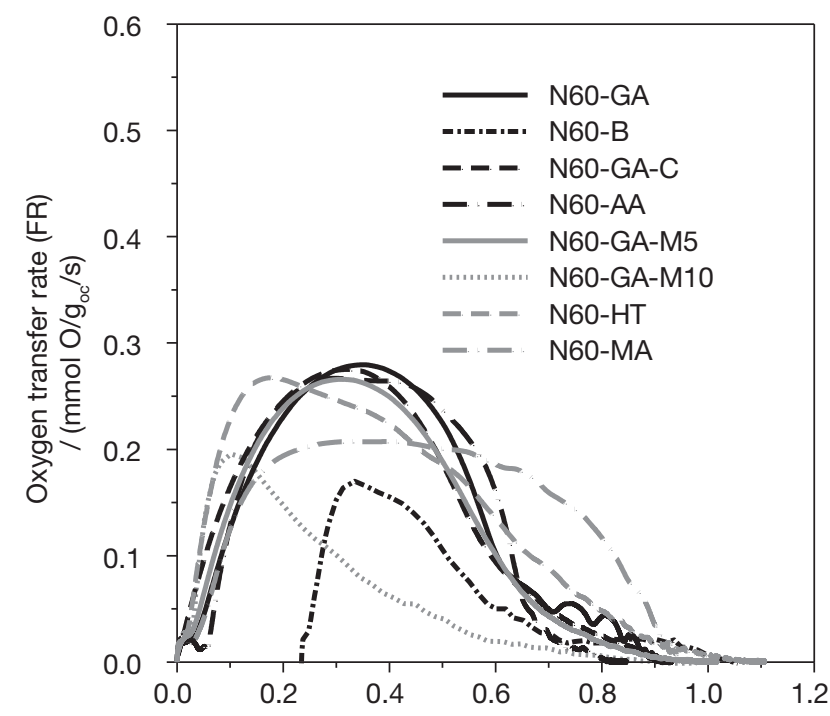

a)

Degree of conversion, $\mathrm{X}$

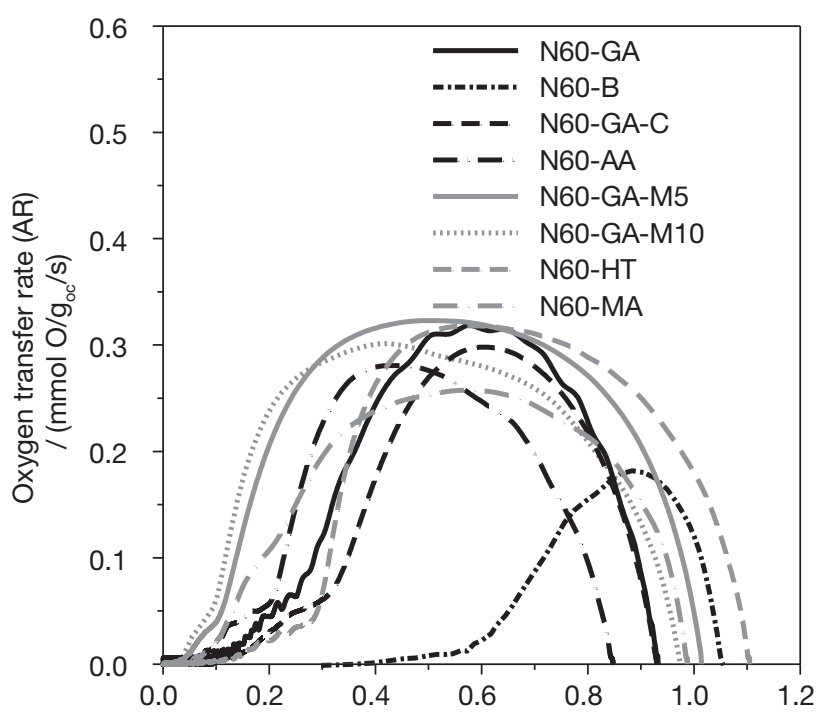

b)

Figure 8

Oxygen transfer rate as a function of degree of conversion in a) the Fuel Reactor and b) the Air Reactor for the oxygen carriers prepared using $60 \mathrm{wt} \% \mathrm{NiO}$ and different raw support materials.

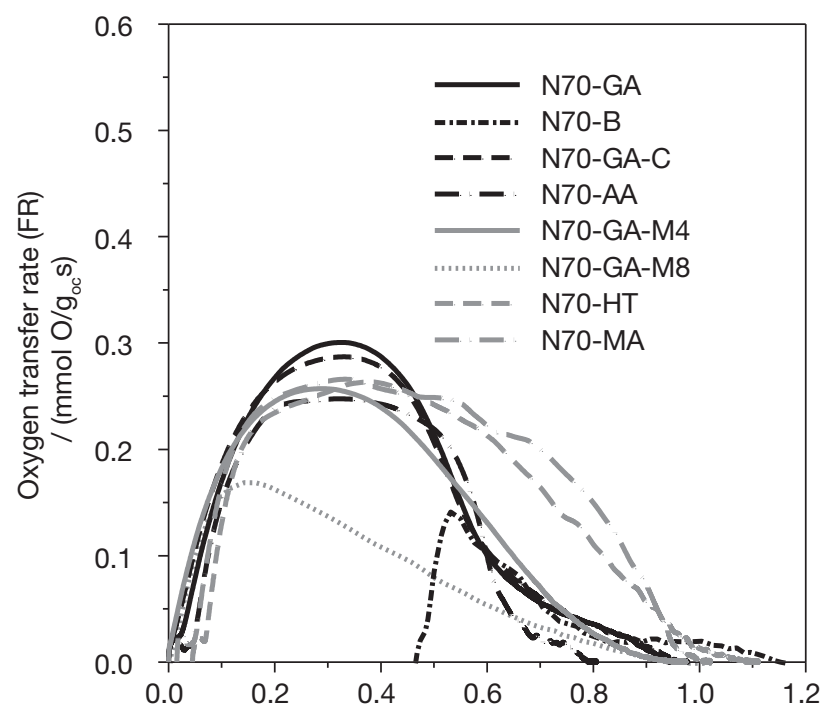

a)

Degree of conversion, $\mathrm{X}$

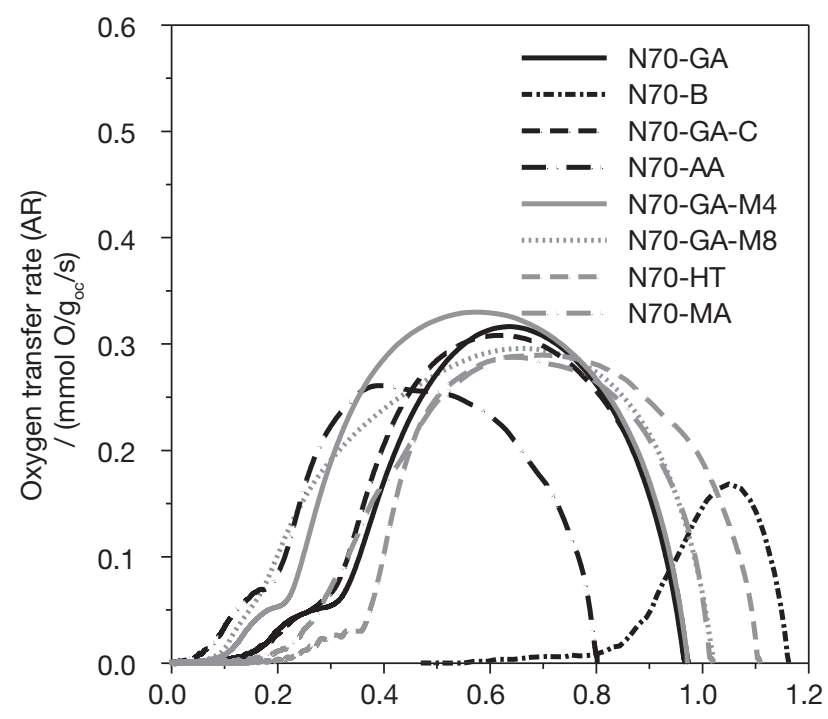

b)

Degree of conversion, $\mathrm{X}$

Figure 9

Oxygen transfer rate as a function of degree of conversion in a) the Fuel Reactor and b) the Air Reactor for the oxygen carriers prepared using $70 \mathrm{wt} \% \mathrm{NiO}$ and different raw support materials. very slowly and its oxygen utilization was $77 \%$, which indicates that a less strong interaction between $\mathrm{NiO}$ and $\mathrm{Al}_{2} \mathrm{O}_{3}$ can be achieved by the use of a high $\mathrm{NiO}$ content.

\subsection{NiO-Support Interaction Study by TPR Analysis}

To explain the differences in reacivities of the prepared oxygen carriers, $\mathrm{H}_{2}$-TPR tests were performed for fresh oxygen carriers and the results are presented in Figure 12. The oxygen carriers prepared using the $\gamma-\mathrm{Al}_{2} \mathrm{O}_{3}, \gamma-\mathrm{Al}_{2} \mathrm{O}_{3}$ with added graphite, and pseudoboehmite transferred most of their oxygen under $700^{\circ} \mathrm{C}$, where free $\mathrm{NiO}$ is primarily reduced. $\mathrm{NiO}$ which interacted strongly with support materials transferred its oxygen to the fuel in a higher reaction temperature zone.

N60-GA-C and N70-GA-C were reduced in the lowest reaction temperature zone. It appeared as if graphite addition 


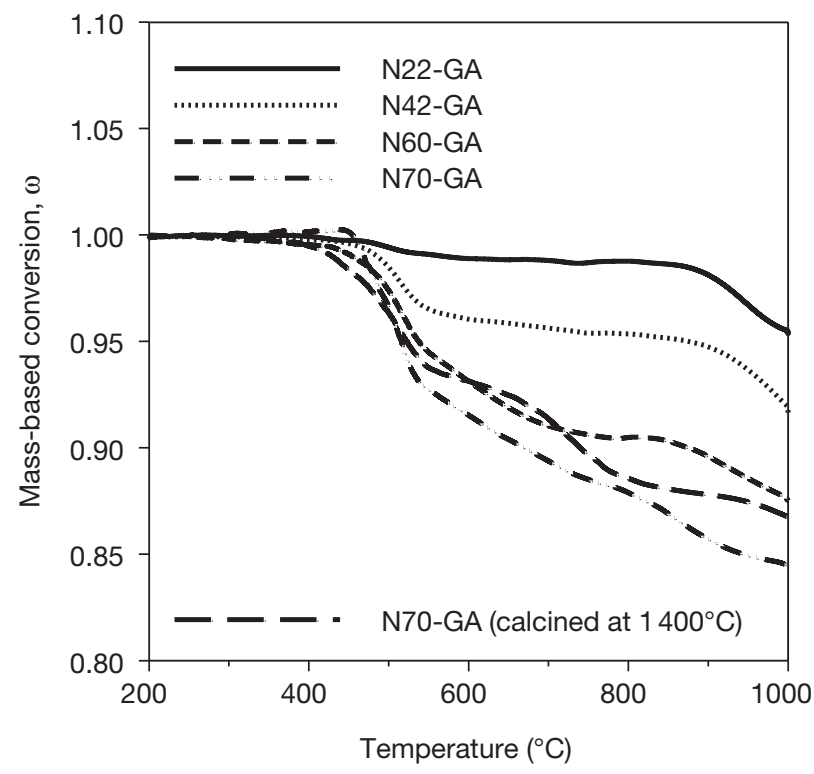

Figure 10

$\mathrm{H}_{2}$-TPR of the fresh oxygen carriers prepared using different $\mathrm{NiO}$ contents and $\gamma-\mathrm{Al}_{2} \mathrm{O}_{3}$.

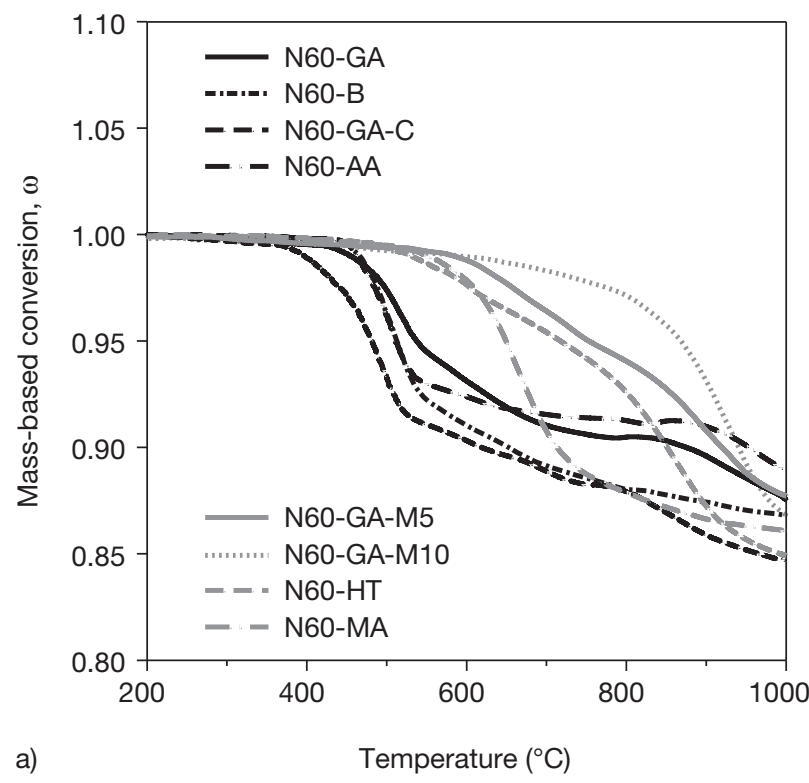

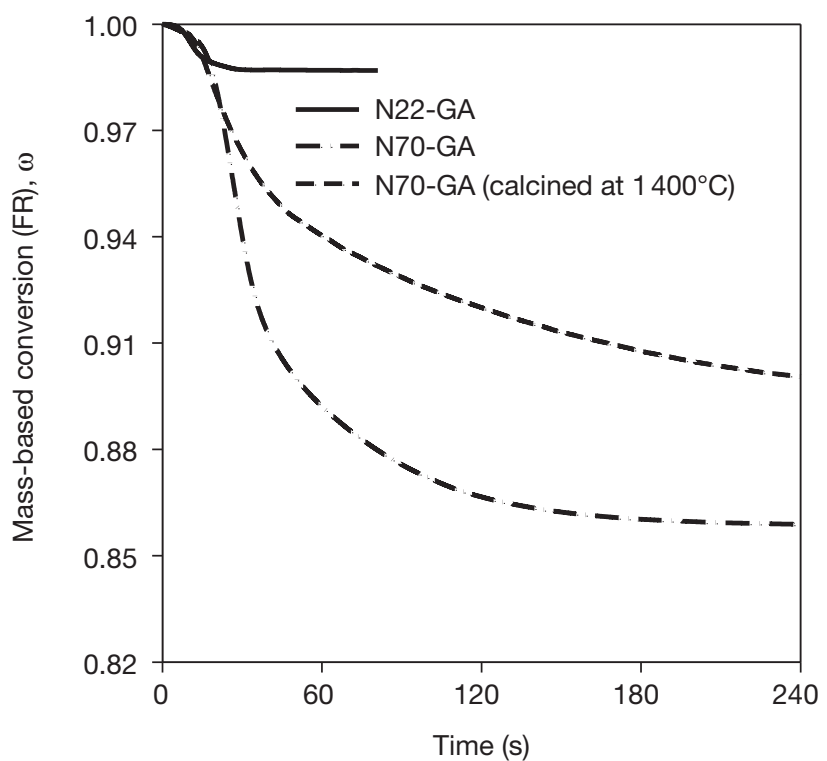

Figure 11

Mass-based conversion as a function of reaction time for the oxygen carriers prepared using $\mathrm{NiO}(\mathrm{NiO}$ content: 22 and $70 \mathrm{wt} \%$ ) and $\gamma-\mathrm{Al}_{2} \mathrm{O}_{3}$.

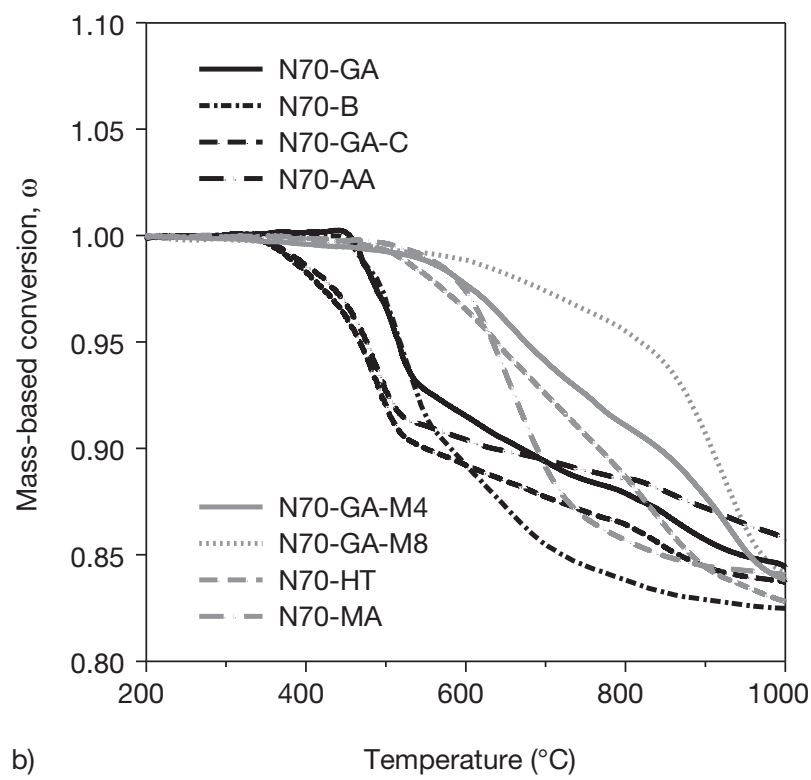

Figure 12

$\mathrm{H}_{2}$-TPR of the fresh oxygen carriers prepared using a) $60 \mathrm{wt} \% \mathrm{NiO}$ and different raw support materials and b) $70 \mathrm{wt} \% \mathrm{NiO}$ and different raw support materials.

was effective for the reduction of the NiO-support interaction. However, in the TGA reactivity analysis there were no apparent differences in reactivity whether graphite was added or not. The discrepancy between TPR analysis and the TGA reactivity analysis seems to be caused by the fact that the initial structure of the fresh N60-GA-C and N70-GA-C became similar to the structure of N60-GA and N70-GA during the cyclic redox reaction. This was confirmed by the fact that N60-GA-C and N70-GA-C showed apparently higher reactivity in the reduction of the first cycle than N60-GA and N70-GA, respectively. 
TPR analysis for the fresh N60-B and N70-B seems to indicate low $\mathrm{NiO}$-support interaction. However, they appeared to agglomerate severely during cyclic redox tests and reactivity decreased considerably from the second cycle, as described in the TGA reactivity analysis. Compared with the N60-GA and N70-GA, N60-AA and N70-AA transferred oxygen in a lower temperature zone at the beginning stage of reduction and transferred more oxygen under $700^{\circ} \mathrm{C}$. However, in the temperature zone over $700^{\circ} \mathrm{C}$, the weight reduction of the N60-AA and N70-AA was smaller than that of the N60-GA and N70-GA. To confirm this phenomenon, new oxygen carriers were prepared using different $\alpha-\mathrm{Al}_{2} \mathrm{O}_{3}$ obtained by calcining the $\gamma-\mathrm{Al}_{2} \mathrm{O}_{3}$ at $1200^{\circ} \mathrm{C}$ for $6 \mathrm{~h}$. The $\mathrm{H}_{2}$-TPR test results for the new oxygen carriers showed almost the same reduction profiles. TPR analysis for the oxygen carriers supported on $\alpha-\mathrm{Al}_{2} \mathrm{O}_{3}$ is in agreement with the TGA reactivity analysis, which showed low oxygen transfer capacity.

The oxygen carriers containing a Mg component were reduced at a higher temperature zone, indicating that NiOsupport interaction was enhanced by the addition of $\mathrm{Mg}$. The oxygen carriers prepared using $\gamma-\mathrm{Al}_{2} \mathrm{O}_{3}$ mixed with a large amount of $\mathrm{MgO}$ required a higher reaction temperature to transfer the same amount of oxygen to $\mathrm{H}_{2}$, indicating the highest $\mathrm{NiO}$-support interaction. This result is consistent with the slow reduction of N60-GA-M10 and N70-GA-M8 in the TGA reactivity analysis. The oxygen carriers supported on hydrotalcite and $\mathrm{MgAl}_{2} \mathrm{O}_{4}$ transferred more oxygen at a lower reaction temperature zone than the oxygen carriers prepared using $\gamma-\mathrm{Al}_{2} \mathrm{O}_{3}$ mixed with $\mathrm{MgO}$, which implies that lower NiO-support interaction could be achieved by the use of hydrotalcite and $\mathrm{MgAl}_{2} \mathrm{O}_{4}$. This is also consistent with the TGA analysis showing fast reduction of N60-HT and N60MA compared with N60-GA-M5 and N60-GA-M8, and fast reduction of N70-HT and N70-MA compared with N70-GAM4 and N70-GA-M8.

\section{CONCLUSIONS}

NiO-based oxygen carriers were prepared by the mechanical mixing method using high $\mathrm{NiO}$ content (60 or $70 \mathrm{wt} \%$ ) and different support materials $\left(\gamma-\mathrm{Al}_{2} \mathrm{O}_{3}\right.$, pseudoboehmite, $\alpha$ $\mathrm{Al}_{2} \mathrm{O}_{3}, \gamma-\mathrm{Al}_{2} \mathrm{O}_{3}$ mixed with $\mathrm{MgO}$, hydrotalcite, and $\mathrm{MgAl}_{2} \mathrm{O}_{4}$ ) to investigate the effect of each support on the reactivity. All oxygen carriers except for the ones prepared using pseudoboehmite and $\alpha-\mathrm{Al}_{2} \mathrm{O}_{3}$ showed high oxygen transfer capacity, transferring more than $90 \%$ of the oxygen in the $\mathrm{NiO}$ added as a raw material. The oxygen carriers prepared using $\gamma-\mathrm{Al}_{2} \mathrm{O}_{3}, \gamma-\mathrm{Al}_{2} \mathrm{O}_{3}$ mixed with a small amount of $\mathrm{MgO}$, and hydrotalcite showed a high reaction rate at both reduction and oxidation. From the comparison of the reactivity of the oxygen carriers, it may be concluded that $\gamma-\mathrm{Al}_{2} \mathrm{O}_{3}$ and hydrotalcite could be desirable raw support materials to obtain highly reactive $\mathrm{NiO}$ oxygen carriers with high $\mathrm{NiO}$ content. In our future work, oxygen carriers for fluidized-bed applications will be prepared on a large scale by the spraydrying method using high $\mathrm{NiO}$ content and the selected support materials $\left(\gamma-\mathrm{Al}_{2} \mathrm{O}_{3}, \gamma-\mathrm{Al}_{2} \mathrm{O}_{3}\right.$ mixed with $\mathrm{MgO}$, and hydrotalcite), and their physical properties and reactivity will be evaluated.

\section{ACKNOWLEDGMENTS}

This work was supported by the Power Generation \& Electricity Delivery R\&D program (2009101010004C) under the Ministry of Knowledge Economy, Republic of Korea. The authors also thank the KEPCO and the five fossil fuel power companies (Korea South-East, Western, Midland, Southern, and East-West Power Company, Ltd.) for their support.

\section{REFERENCES}

1 Abad A., Adánez J., García-Labiano F., de Diego L.F., Gayán P., Celaya J. (2007) Mapping of the range of operational conditions for $\mathrm{Cu}-, \mathrm{Fe}-$, and Ni-based oxygen carriers in chemical-looping combustion, Chem. Eng. Sci. 62, 1-2, 533-549.

2 Adánez J., de Diego L.F., García-Labiano F., Gayán P., Abad A., Palacios J.M. (2004) Selection of oxygen carriers for chemical-looping combustion, Energ. Fuel. 18, 2, 371-377.

3 Wolf J., Anheden M., Yan J. (2005) Comparison of nickel- and iron-based oxygen carriers in chemical looping combustion for $\mathrm{CO}_{2}$ capture in power generation, Fuel 84, 7-8, 993-1006.

4 de Diego L.F., García-Labiano F., Adánez J., Gayán P., Abad A., Corbella B.M., Palacios J.M. (2004) Development of $\mathrm{Cu}$-based oxygen carriers for chemicallooping combustion, Fuel 83, 113, 749-1757.

5 Johansson M., Mattisson T., Lyngfelt A. (2006) Investigation of $\mathrm{Mn}_{3} \mathrm{O}_{4}$ with stabilized $\mathrm{ZrO}_{2}$ for chemicallooping combustion, Chem. Eng. Res. Des. 84, 9, 807818.

6 Cho P., Mattisson T., Lyngfelt A. (2004) Comparison of iron-, nickel-, copper- and manganese-based oxygen carriers for chemical-looping combustion, Fuel 83, 9, 12151225.

7 Gayán P., de Diego L.F., García-Labiano F., Adánez J., Abad A., Dueso C. (2008) Effect of support on reactivity and selectivity of Ni-based oxygen carriers for chemicallooping combustion, Fuel 87, 12, 2641-2650.

8 Zafar Q., Mattisson T., Gevert B. (2006) Redox investigation of some oxides of transition-state metals $\mathrm{Ni}, \mathrm{Cu}, \mathrm{Fe}$, and supported on $\mathrm{SiO}^{2}$ and $\mathrm{MgAl}_{2} \mathrm{O}_{4}$, Energ. Fuel. 20, 1, 34-44. 
9 Mattisson T., Järdnäs A., Lyngfelt A. (2003) Reactivity of some metal oxides supported on alumina with alternating methane and oxygen - application for chemical looping combustion, Energ. Fuel. 17, 3, 643-651.

10 Mattisson T., Johansson M., Lyngfelt A. (2004) Multicycle reduction and oxidation of different types of iron oxide particles-application to chemical-looping combustion, Energ. Fuel. 18, 3, 628-637.

11 Mattisson T., Johansson M., Lyngfelt A. (2006) The use of $\mathrm{NiO}$ as an oxygen carrier in chemical-looping combustion, Fuel 85, 5-6, 736-747.

12 Ishida M., Jin H. (1996) A novel chemical-looping combustor without NOx formation, Ind. Eng. Chem. Res. 35, 7, 2469-2472.

13 Jin H., Okamoto T., Ishida M. (1999) Development of a novel chemical-looping combustion: Synthesis of a solid looping material of $\mathrm{NiO} / \mathrm{NiAl}_{2} \mathrm{O}_{4}$, Ind. Eng. Chem. Res. 38, 1, 126-132.

14 Shulman A., Linderholm C., Mattisson T., Lyngfelt A. (2009) High reactivity and mechanical durability of $\mathrm{NiO} / \mathrm{NiAl}_{2} \mathrm{O}_{4}$ and $\mathrm{NiO} / \mathrm{NiAl}_{2} \mathrm{O}_{4} / \mathrm{MgAl}_{2} \mathrm{O}_{4}$ oxygen carrier particles used for more than $1000 \mathrm{~h}$ in a $10 \mathrm{~kW}$ CLC reactor, Ind. Eng. Chem. Res. 48, 15, 7400-7405.

15 Bera P., Rajamathi M., Hegde M.S., Kamath P.V. (2000) Thermal behaviour of hydroxides, hydroxysalts and hydrotalcites, B. Mater. Sci. 23, 2, 141-145.
16 Speakman S.A., Payzant E.A. (2004) Structural effects on the high temperature adsorption of $\mathrm{CO} 2$ on a synthetic hydrotalcite, Chem. Mater. 16, 21, 4135-4143.

17 Linderholm C., Jerndal E., Mattisson T., Lyngfelt A. (2010) Investigation of NiO-based mixed oxides in a 300W chemical-looping combustor, Chem. Eng. Res. Des. $\mathbf{8 8}, 5-6,661-672$.

18 Jerndal E., Mattisson T., Lyngfelt A. (2009) Investigation of different $\mathrm{NiO} / \mathrm{NiAl}_{2} \mathrm{O}_{4}$ particles as oxygen carriers for chemical-looping combustion, Energ. Fuel. 23, 2, 665676.

19 Kuusik R., Trikkel A., Lyngfelt A., Mattisson T. (2009) High temperature behavior of $\mathrm{NiO}$-based oxygen carriers for chemical looping combustion, Energy Procedia 1, 1, 3885-3892.

20 Jerndal E., Mattisson T., Thijs I., Snijkers F., Lyngfelt A. (2009) $\mathrm{NiO}$ particles with $\mathrm{Ca}$ and $\mathrm{Mg}$ based additives produced by spray-drying as oxygen carriers for chemicallooping combustion, Energy Procedia 1, 1, 479-486.

21 Linderholm C., Mattisson T., Lyngfelt A. (2009) Longterm integrity testing of spray-dried particles in a $10 \mathrm{~kW}$ chemical-looping combustor using natural gas fuel, Fuel 88, 11, 2083-2096.

Final manuscript received in October 2011 Published online in A pril 2011 